\title{
The Development of Digital Sign Language Dictionary for Hearing Impaired
}

\author{
Hermawan, Mohammad Anwar, Donni Prakosha \\ Sebelas Maret University \\ Solo, Indonesia
}

\begin{abstract}
The specific aim of this research is to develop a Digital Signal System (SID) used in standardized, patented, Digital Sign Language Dictionary (KBID), and is used for all hearing impaired. The target of this research in the first year is the development of KBID beta. While in the second year is a standardized SID and used for all hearing impaired in communication, and KBID can be used by teachers and parents. Stages of research that has been done as a researched planning, FGD of sign language concepts in Indonesia, data collection, and design development. The next stage will be a limited-scale trial, revision of trial results and large-scale trials. The results of the first phase showed that there was a significant difference between BISINDO and SIBI. In addition, hearing impaired who use BISINDO face difficulties in understanding the subject of Bahasa Indonesian at school, especially complete and structured sentences.
\end{abstract}

Keywords - Digital Sign Language Dictionary, Sign Language, hearing impaired.

\section{INTRODUCTION}

Hearing impairment is a disorder of the sense of hearing. Haenudin [1] stating that the hearing impaired is someone who lacks or loses the ability to hear caused by the malfunctioning of the hearing instrument. In the process of language development in human, the first stage begins with the process of listening. The existence of problems in the hearing process causes obstacles in the reception of information in a conversation so it affects the ability to speak. These obstacles affect the difficulty of someone to deliver information to others.

The hearing limitation of children with hearing impairment affects the process of hearing the language of a child with hearing impairment only through the senses of vision and residual hearing. Most people do not understand sign language. In addition, the sign language used was a self-taught sign language. Besides, the signs used were the result of the exploration of childhood in the environment of everyday life. Therefore, it was found that sign language is different from one region to another.

Based on the reason above, it was very important to develop a tool or media that can help the hearing-impaired people in order to communicate each other. Through this research, it was developed digital signaling system (SID) and digital sign language dictionary (KBID). SID and KBID were applications composed by combining sign language with various digital elements including text, sound, image, animation, and video so that it can be operated and controlled by the user digitally. The current Indonesian Sign Language System (SIBI) dictionary is one of media that helps the hearing impaired to communicate in wider society [2]. Digital sign dictionary contains a variety of menus and sub menus adjusted to the hearing-impaired children and material given. Digital sign dictionary contains gesture, oral, alphabet, audio, and image video that comes with a label combined with animation. Purnama [3] states that multimedia was a combination of digitally manipulated text, photos, art, graphics, sound, animation, and video elements. In addition, Vaughn [4] suggests that multimedia is a combination of text, art, sound, images, animation, and video delivered with computers or manipulated digitally and can be delivered or controlled interactively. The varied content is very much in line with the hearing-impaired children's speech so that the sense of vision of the hearing-impaired children can be optimal in obtaining information.

\section{METHOD}

This research was a kind of Research and Development ( $R$ $\&$ D) because this research aimed to develop a product. The product developed in this research is Digital Sign Language Dictionary (KBID). The research will be conducted for 2 years. In the first year, the product developed is Digital Signal System. While in the second year, the product to be developed is Digital Sign Language Dictionary (KBID).

Subjects of the test who used in this study were 25 students with hearing impairment at SLB B YRTRW Surakarta in the academic year of 2016/2017. The students consist of 15 female students and 10 male students. The technique used to determine the research sample is purposive sampling. Purposive sampling was one of the techniques of determining the sample with some specific considerations from the researchers.

\section{RESULT AND DISCUSSION}

The result of the research included the results of several stages of research that have been done. The research that has been done includes 7 stages, namely 1) research planning, 2) FGD concepts of sign language in Indonesia, 3) data collection and analysis, 4) design development, 5) data analysis, 6) limited scale test, and 7) large scale test. The whole stages of the research ware conducted to collect data and test the products to be developed in this study. 
The first stage was the stage of research planning. The research began with preparatory meeting activities. The preparatory meeting was conducted on $3^{\text {rd }}$ June 2017 which was attended by the chairman and researcher members. In addition, some students were also involved to be assistant of research. This preparatory meeting aimed to prepare the roles and responsibilities of each research member. To make the implementation of research could be done regularly and on schedule, time schedule was also arranged in this preparatory meeting.

The next research stages were the Forum Group Discussion (FGD) concept of sign language used in Indonesia. In this FGD activity, a discussion about the system or concepts of sign language used in Indonesia was issued. Indonesia has several versions of sign language. Indonesia has established SIBI as the standard gesture used by hearing impaired people in Indonesia. However, most of them are still reluctant to use the type of sign language because the use of the type is too long to be used for speaking and is considered too difficult to learn. For this reason, they developed another sign language beside SIBI. The sign language developed is BISINDO.

The development of non-standardized sign language in Indonesian raised some problems, especially in the school environment. When the hearing impaired are accustomed to use BISINDO as their sign language, the school uses SIBI as the determined sign language to deliver lessons. Based on the problem, the researchers conducted FGD on $17^{\text {th }}$ until $18^{\text {th }}$ June 2017. The FGD activities included hearing impaired people's speech representatives from the deaf community, teachers from special school and inclusion schools, sign communication experts, and stakeholders. Through the FGD, researchers managed to identify some problems that cause deadlock. Therefore, the research team needs to conduct more in-depth study. To obtain the necessary data for materials, the research team took the data directly in the special school and the community.

The data collection process was conducted by a team of researchers consists of 15 people. The time required for data collection was 10 days from $10^{\text {th }}$ July 10 to $28^{\text {th }}$ July 2017 . There were three places used for data collection. Those locations were special schools (SLB), inclusive schools, and deaf communities. The researchers collected data directly from the three places. Data was collected by using recording technique.

There were several activities used and taken as data in this study. Those activities are 1) activities when hearing impaired students are learning in the classroom, 2) activities when hearing impaired people communicate, 3) activities when hearing impaired people interact with the community, and 4) interviewing activities with parents of students with hearing impairment. In the first activity, researchers recorded and noted the process of students in the teaching learning process in the classroom. In addition, researchers also pay observed teachers when delivering material to them.

The second activity is the activity when students with hearing impairment, especially when they communicate in the school environment. In this activity, researchers recorded their processes when communicating with both students with hearing impairment or with normal students. Researchers observed the way they communicate, which used a sign in language, and how are their responses.

The third activity is when students or people with hearing impairment interact with the community. In this activity, researchers observed the way they communicate, but unlike the second activity. In the second activity, researchers observed their way to communicate in the school environment only. While at this third stage of activity, researchers observed their activities when they communicate within the community. Researchers recorded how they communicate, what type of sign language they use, and how are their responses.

The fourth activity was an interview with the parents of the hearing-impaired students. The data which is taken from this activity is an answer or response from the parents of hearingimpaired students. Researchers asked some questions related to how they communicate, difficulties, obstacles, or their responses. Their answers or responses became the data used in this study.

The product developed in this research is a technologybased product. Researchers have limitations in terms of technology. Limitations of researchers in terms of technology makes researchers need help from the experts of technology. With that reason, the research team worked with IT experts to develop this application.

From the entire data that has been collected by the researchers, data analysis was then conducted. The collected data was analyzed qualitatively and quantitatively. A qualitative analysis was conducted to determine or identify some of the different elements between BISINDO and SIBI. While quantitative data analysis conducted to obtain statistical data that support the development of the concept.

The next step was a limited-scale test. The prototype of this application was tested on a limited scale at the beginning of October 2017. There are some parties involved in the implementation of this trial, i.e. IT experts, hearing impaired people, teachers from special school, and sign language experts. The results obtained from the limited-scale test were revised and reviewed so that they would be ready to be tested on a wider scale. The results of this activity were the suggestions from the test participants after testing the prototype of the application of sign language dictionary, either from the point of substance, layout, or the validity of the content or in this case the sign language itself.

After conducting a review and revision from the results of a limited-scale trial, the researcher made improvements to digital sign language applications based on suggestions from participants on a limited-scale trial. The improvement of the application is further tested on a wider scale than before. This large-scale pilot activity was carried out in the third week in October 2017. The location of this large-scale test site was in special schools, inclusive schools, and deaf communities in Solo. 


\section{CONCLUSION}

The results of the first stage showed that there was a significant difference between sign language of BISINDO and SIBI. The most basic principle is the letter or alphabet $\mathrm{A}-\mathrm{Z}$. On the alphabetical sign, there were only two same letters between BISINDO and SIBI. Other finding is that the students with hearing impairment who use BISINDO get some difficulties in understanding subject of Bahasa Indonesia, especially about complete and structured sentences. This finding is very important as a basis to form the basic concepts of new sign language. It can be concluded that this study needs to be conducted again in the second year.

\section{REFERENCES}

[1] H. Haenudin, Pendidikan anak berkebutuhan khusus tunarungu, Jakarta: PT Luxima Metro Media, 2013.

[2] D. Depdiknas, Pendidikan luar biasa dalam angka, Jakarta: Direktorat PSLB, 2008.

[3] B.E. Purnama, Konsep dasar multimedia, Yogyakarta: Graha Ilmu, 2013.

[4] S. Vaughn, C.S. Bos and J.S. Schumm, Teaching exceptional, diverse, and at risk students in the generl education classroom, Boston: Allyn Bacon, 2005. 